\title{
Reconstructing the history of Panji performances in Southeast Asia
}

\author{
ADRIAN VICKERS
}

\begin{abstract}
The circulation of Panji stories throughout Southeast Asia has been studied as a textual phenomenon. These same texts, however, provide evidence of how theatrical forms were important as a source for the dispersal of Panji stories. The textual evidence demonstrates that dance-dramas presenting Panji stories were performed in Majapahit times. These dance-dramas, known as raket are continued in the gambuh of Bali as well as in Javanese topeng. They were also widely known in the Malay world, and were connected to Thai and Cambodian theatrical forms.
\end{abstract}

\section{KeYWORDS}

Panji; theatre; performance; Southeast Asia; gambuh; raket.

The origins and spread of stories of the Panji figure - the romantic roaming prince - in Southeast Asia have been well-documented, both in terms of their diversity and their origins (Overbeck 1932a; Saleh 1988; Robson 1996; Kieven 2013). In their dispersal from Java to Myanmar and Cambodia, via the Malay Peninsula, Panji narratives have been presented in a variety of media. The written forms of the stories have been discussed by many scholars and some stories were extensively documented (Poerbatjaraka 1940; Puaksom 2007), but it is more likely that it was through oral means and performance, rather than manuscripts, that the narratives spread. Although scattered, the evidence of performance demonstrates how it is possible to reconstruct earlier forms,

\footnotetext{
ADRIAN VICKERS holds a personal chair at the University of Sydney, and researches and publishes on the cultural history of Southeast Asia. He has held a series of Australian Research Council grants, the most recent looking at Indonesian art, the Cold War, and labour and industry in Southeast Asia. As part of a linkage grant on the history of Balinese painting, he has created The Virtual Museum of Balinese Painting <balipaintings.org>, continuing previous pioneering work in eResearch and teaching. His books include the highly popular Bali; A paradise created (new edition 2012), A history of modern Indonesia (new edition 2013), Balinese art; Paintings and drawings of Bali, 1800-2010 (2012), and (co-authored with Julia Martínez, 2015) The pearl frontier; Labor mobility across the Australian-Indonesian maritime zone, 1870-1970, which won two book awards. Adrian Vickers is a Fellow of the Australian Academy of the Humanities. Adrian Vickers can be reached at: adrian.vickers@sydney.edu.au.
}

(C) 2020 Faculty of Humanities, Universitas Indonesia

ADRIAN VICKERS | DOI: 10.17510/wacana.v21i2.897. 
especially through understanding of Balinese gambuh dance-drama.

A variety of performance forms involving Panji stories is still practised throughout Southeast Asia. Some of these, such as Javanese topeng, have a healthy basis in local communities, particularly in north and east Java (Ross 2016). Others, such as Kelantanese wayang jawa, are threatened with extinction, while others such as Cambodian roeung-Eynao (Moura 1883 Vol. II: 414-444), have had to be revived following the devastation of the 1970s. Many of the written Panji texts display aspects of performance in a reflexive fashion and it is through these written sources that it is possible to reconstruct aspects of the history of Panji performances.

Why is it significant to know about these performances? Overbeck (1927, 1932a, 1932b), in his articles that canvassed some of the data, argued that through textual sources we could find the original form of all Indonesian theatre, in particular the wayang wong or Central Javanese dance-drama presenting Indic narratives. In the style of anthropology of the time, Overbeck sought to connect these theatrical forms to ancient Polynesian performances.

Evidence for these performance traditions can be found in the visual Panji story tradition. East Javanese reliefs showing Panji stories date to at least 1413 CE (Poerbatjaraka 1940:366; Kieven 2013). There is also a Javanese tradition of painting called wayang beber, where scroll paintings are performed by a dalang, a style of visual story-telling known also in northern India. The wayang beber in its present form depicts Panji stories, although the oldest extant scrolls date to the end of the seventeenth century $1692 \mathrm{CE}$ according to a chronogram on one of the scrolls). A history of these scrolls and their performances from the court of Surakarta has it that they descend from an original created by a king of Majapahit in 1378 CE (Sayid 1980: 8,11). Chinese sources show that a form of painting very similar to wayang beber existed in Majapahit times, although the wayang beber story needs to be treated with great caution (Anderson 1974: 34-35; Kant-Achilles 1990: 22).

Panji stories have been maintained in Balinese culture both through an abundance of written sources and through the strength of the dance-drama known as gambuh, which is regarded as the "classic" originary or at least paradigmatic version of other Balinese forms (Vickers 2005). The Panji stories presented in gambuh are mainly found in the lengthy text known as Malat or Kidung Panji Amalat Rasmi, manuscripts of which date back to at least 1725 $\mathrm{CE}$, indicating that this particular version of the story may go further back, to the seventeenth century (Vickers 2005).

\section{PUPPETS FORMS}

The name of wayang beber - 'scroll or unfurled shadow theatre' - shows the primacy of theatrical forms in Javanese cultural traditions. The puppet form used to present Panji stories in Java is usually known as wayang gedhog (Gunning 1896) and was once highly prevalent. The Malat also refers to a wayang form known as wayang gambuh, in which stories similar to the Panji narratives are performed. 
One written passage, found in a number of Malat manuscripts, narrates a puppet performance which seems to come from stories known in 'Middle' or tengahan metric form of the kidung poems, the form usually used for Panji and related narratives. ${ }^{1}$ The episode tells the story of how the protagonist Panji and his cousin (whose identity is concealed), the young king of Malayu, are together in the mountains with their wives and entourages, and they hold wayang performances at night. The performance takes place not long before Panji is finally united with Rangkesari (his cousin, and Malayu's sister), his lost object of desire. After wandering in the forest, where Panji has his first real physical contact with Rangkesari, albeit one that he still thinks is adulterous because he believes her to be his friend Malayu's wife, all return to their camp. At first Malayu is invited by his companion Kebo Angkawa to perform as puppeteer. So, he performs the story of "The death of Abimanyu", called a wayang prawa (parwa in current Balinese usage), or classical wayang story known from the Indic kakawin text the Bharata Yuddha, telling about the climactic battle from the Mahābhärata. Kebo Angkawa accompanied this by playing the gendèr, the metallophones using vertical bamboo resonators which accompany the wayang in current Balinese practice. The king's performance of the story moves the audience to tears at the death of the hero, but he is praised for his comic scenes (awayang bañol).

When the king finishes, he hands over the shadow play performance to his companion Rangga Jalada, who performs a different wayang, a wayang carita or'story wayang', which Kuda Senetan accompanies with the different bamboo instruments called guntang. The story is that of Dalang Jaruman ('The Puppeteer Intermediary'), not a story known now in Bali or even found in texts other than the Malat, but apparently about a king disguised as a puppeteer. This passage not only illustrates the nature of the particular form of the shadow theatre called wayang carita, but also shows the associations of romantic play involved in Malat-like texts. In this description the wayang carita performance is accompanied by the singing of kidung and the playing of guntang music ${ }^{2}$, which seems to have involved the use of bamboo instruments. The performance has the effect of making the audience feel emotions of love (Vickers 2005: 107-110).

Various characters with titles found in kidung poems and gambuh are mentioned in this description, especially Semar, the servant-cum-clowncum-interpreter familiar from gambuh. During a second performance of the wayang carita the story of "Misa Padapa when captured by Kebo Sinom Kapati" is presented, accompanied by singing of the kidung verse Ukir Polaman Raspati (13.72). The picture that emerges from these narratives is that puppet performances using kidung musical styles and now-unknown stories similar to those found in Panji narratives were well-known in Bali, and familiar to eighteenth- and possibly seventeenth-century audiences. This evidence

\footnotetext{
${ }^{1}$ The manuscript used here is Gedong Kirtya 405, Canto 11.78ff, see Vickers 2005.

2 Similar musical instruments are used in arja dance-drama in Bali, which includes Panji stories in its repertoir.
} 
indicates that the wayang carita is most likely the original form of what is now known as wayang gambuh in Bali.

Wayang gambuh is a relatively little-known form in Bali, but the available evidence indicates that a number of the Balinese royal houses had sets of these puppets. There are two surviving versions of these puppet sets, one formerly associated with the former kingdom of Badung, another with the house of Blahbatuh. Both puppet sets are regarded as highly sacred and difficult to get to see, but the evidence of the owners of these puppets is that their form is the same as that of the wayang gedog in Java. Wayang gedog performances narrate Panji stories, and in Javanese sources date back to $1563 \mathrm{CE}$, when they were invented by the saints who brought Islam to Java. From the puppet form, the masks for Javanese performances were made in 1586 CE (Pigeaud 1938: 53). Oral history of the origins of the Blahbatuh set of puppets has it that this was one of two sets taken from East Java by the rulers of Mengwi. This story is told by those connected with the famous temple of Seseh, which commemorates the death of one of the princes of Blambangan in East Java who was a prisoner in Mengwi. The one set was eventually taken to Blahbatuh, where it was owned by the princes there who had captured it in Java, and was later returned to the family of the puppeteers when the princes could no longer afford to keep it. The other set was taken to Lombok and became the model of the wayang sasak or main Lombok form of wayang, which uses the iconography of the wayang gedog. ${ }^{3}$ An alternative oral history has it that the wayang gambuh came from Java via North Bali when the kings of Buleleng conquered that part of the larger island (Hinzler 1981: 31). Another set of wayang gambuh was created in a style closer to modern Balinese forms. Oral history has it that it was made in Sukawati in 1774, with a set copied from the Sukawati one made in KabaKaba village, and later given to the mid-twentieth-century performer Sabug, when the set was being dispersed. Other similar sets are said to have existed in Pedungan and Kedaton. ${ }^{4}$

\section{MAJAPAHIT ORIGINS?}

The name wayang gambuh indicates that this is a shadow-puppet form of the dance drama gambuh, a form much more widely known on Bali, albeit one that is regarded as archaic. A Balinese text concerned with gambuh describes the form as a mixture between Balinese and Javanese movements, dating to the history of King Udayana in the tenth century:

Sri Udayana suka angetoni wang Jawa mangigel, sia anunggalaken sasolahan Jawa mwang Bali,

angabungaken ngaran gambuh, kala isaka lawang apit lawing (929).

3 Field interviews Blahbatuh, 1981-1983.

4 Field interviews, 1981-1983. 
King Udayana watched the Javanese people dance, and united the Javanese movements

with Balinese, uniting them under the name of gambuh in the year CE 1009 (Bandem et al. 1975: 4).

It is very likely that the source of this information was a twentieth-century text, but it shows Balinese perceptions that gambuh and Javanese forms were connected. This is, however, flimsy historical evidence, given that there are not similar accounts in older manuscripts. Other Balinese texts have it that gambuh was brought to Bali in 1455 by the Majapahit noble installed to rule Bali, Sri Dalem Smara Kepakisan, who brought the gambuh narrative Amad-Mohammad (Rinda and Moerdowo 1973: 2). Given that the text mentioned presents stories of the Islamic world, it is likely that it is an anachronistic reference. Rather, a variety of texts not only from the Javanese-Balinese tradition, but from the Malay world, show that the picture is more complex.

The term gambuh appears in at least one Balinese text that pre-dates the Malat, which gives clues to occurrences of the word in other parts of Southeast Asia, notably in Malay texts, indicating a wider role in a common discursive formation. The Balinese poem Kidung Wangbang Widéya has the earliest reference to gambuh (Robson 1971 canto 1.59-60), where it is equated with a dance form called raket. Manuscripts of the Wangbang Widéya date to early seventeenth-century east Bali. This reference is an important lead to tracing Panji performances back to the kingdom of Majapahit.

The Panji poem Wangbang Widéya describes itself as a carita wayang anteban inapi, "a tale of the wayang anteban put into verse" (Robson 1971: 240-241). In more recent times, dalang anteban is the designation given to a certain type of puppeteer, one who has studied wayang as an assistant to another dalang (the role is called juru tanceb), but who is illiterate, and thus learnt his art only from performances and non-literary influences. ${ }^{5}$ If this is the meaning intended by the poet of Wangbang Widéya, then he is showing the modesty demanded of a traditional poet by not claiming to be especially accomplished at literature. However, he is also confirming the view that literary texts can be seen as wayang stories in verse form.

Wangbang Widéya describes a palace performance. The protagonist, Panji has his followers perform a 'new gambuh' (gambuh anyar). One of these followers, Banyak Tarawarsa, performs the music. Another, Rangga Wicitra, takes a role of "Kula(n)te", while another, Jaran Wirapaksa, performs the role of a priest, Dang Guru, while a fourth, Carang Lengkara, tells jokes. The performance is also called raket (Wangbang Widéya [Robson 1971] I, 59a-60b).

The lexiconographer, H.N. van der Tuuk, who lived in north Bali in the nineteenth century, used Balinese and Old Javanese (Kawi) sources to describe raket as a masked performance with a number of players (1897-1912: under the word sv raket). ${ }^{6}$ The same term occurs in a number of older texts, dating between the tenth- and fifteenth centuries, namely the Ädiparwa, Arjunawiwāha, Smaradahana, Ghatotkacasraya, and Sumanasantaka. In these texts there is no detail as to the nature of the performance, as is also the case of its uses in later 
kidung texts, notably the Harsawijaya $(6.91,17.11)$ and Tantri Kadiri (1.63b) (Zoetmulder 1982: under the word raket).

Van der Tuuk did not know of the major Majapahit text Deśawarnana or Nagarakertagama (Robson 1995), which only came to Western knowledge after the Dutch invasion of Lombok in 1894. This text uses the word raket to describe a performance. The key passage from the text is from canto 66.5:

Sāsing kārya maweha tușta rikanang para jana winangun nareśvara huwus

nang widwāmacangah rakĕt-rakĕt anganti [A aganti] sahana para gìtada [A śitada] pratidina

anyat bhäta mapatra yuddha sahajang magĕlagĕlapan anggyat angdani pacĕh [A pasĕh] mukyang dāna ri salwir ing manasi tan pĕgat amuhara harșa ning sabhuvana ${ }^{7}$

Stuart Robson translates this passage as

Every performance that might please the people the King held:

See the storytellers and masked dancers taking turns with all kinds of strangers every day!

Not to mention the warriors shouting challenges - naturally the ones as loud as thunderclaps gave people a fright and made them laugh,

And in particular the constant donations to every kind of person begging alms caused everyone to be joyful.

Raket is described in greater detail later in the text, in canto 91:

4. hāryya raṇādikāra lali yan hatur i narapati, hāryya mahädikāra ta dulur nika paṛn amuwus, ān para handyan āpti mihate siran arakhĕrakhĕt [A narakeraket], à juga linnirā t-hĕr umāntuk hadadadakan.

5. śrì krtawardhaneśwara mamañjaki sira rumuhun, ṅkāna rika [A rikang] witāna ri triah rinacana dinadak, sorinireki gitada lawan tkěsira rahajön, sotan ulah karāmyan ikanan் guyu juga winan்un.

6. ndāluwaran sireki ri datan் [A datang] narapatin anadĕg, gìtanirānyat andani gìrahyasen in umulat [A nikangumulat], śoranireki suśrama nirukti lituhayu wagĕd, gita nikānhiribhirib aweh ṛsěpanin umulat.

7. śrì naranātha tan sipi wagusnira tlas arasuk, așta tkĕsnirekin upabhāryya rahayu sawala, tusnin amatya wańśa [A wañśaja] wicakșaṇa tĕtĕs in ulah, etunirān pabañwal anibākĕn ucapan añne.

7 Thanks to Wayan Jarrah Sastrawan for alternative readings and discussions of these manuscripts and other issues, the main one based on the Cakranagara manuscript used by Pigeaud 1960-1962 (C), with alternative readings from an Amlapura manuscript (A) now in the Pusat Dokumentasi Bali, a copy of the MS from Geria Pidada Sidemen, which was also copied by Dewa Gede Catra for the Tantular Museum in East Java. 
8. nan் nawanātya kapwa tinapaknira tinĕwĕkakĕn, asya makādi tan pat [A tan pegat] ikan் guyu parn் aslur, mwan் karuṇāmañun tanis aweh skĕl apuhara luh, etu nikañ tumon pada kamānuṣan an̈ĕnàiĕn.

In Robson's translation, this is:

4. Ārya Ranāshikāra had neglected to address the King, So Ārya Mahādhikāra joined him to say together That the nobles desired to watch him perform raket 'Ah!' was all he said, and went back to make an improvisation.

5. Prince Krtawardhana acted as pañjak for him in the meantime; There in the hall in the centre it was hastily arranged. His Śori was a singer, and his Tekes was Rahajeng Seeing it was for the sake of amusement, it simply aroused mirth.

6. He withdrew when the King arrived to take up his role:

His song was of a different kind, causing the onlookers to be delighted.

His Śori was brisk, fittingly handsome and accomplished, And the latter's song made veiled allusions, giving the onlookers deep pleasure.

7. The King was exceedingly handsome, in his full costume, And he had eight Tekeses who, being his minor wives, were truly beautiful. They were of noble descent, clever and thoroughly versed in what to do, So when he did the jesting-scene they let comments drop that were to the point.

8. In this way he went right through the Nawanātya and took it as his starting point, With farce as first principle - the laughter was constant, in unison and unbroken,

And also pathos, which made people weep, inspired sorrow and ended in tears,

So that the audience were overwhelmed with emotion.

There are multiple problems that make this passage difficult to interpret. Two of the key terms that Robson, following Pigeaud, interprets as roles in the dance have other possible meanings. Śri could also mean 'Queen', in accordance with other usage, that is that the Queen of Majapahit sang, and later accompanied the King in dancing. Likewise, Rahajeng, which Robson interprets as a name, could simply mean 'beautiful'. This possibility lies behind the alternative interpretation of I Ketut Riana (2009: 433-437), who provides the interpretation "The Queen (Dyah Śori), wore a beautiful crown while continuing the song". This interpretation follows Balinese practice, where mamañjaki means 'to drum' (compare Pigeaud 1938: 503). ${ }^{8}$

${ }^{8}$ Riana's interpretation of $4 \mathrm{~d}$, " $\overline{\mathrm{A}}$ " as "yes" fits with modern Balinese usage (Aa), but the Old Javanese meaning of "oh" may be more likely. The text that Riana uses is nevertheless 
One problem in Riana's interpretation is that he subsequently has to reinterpret $7 \mathrm{~b}$ as "Eight followers wore headdresses of various types". ${ }^{9}$ Riana glosses over nawanatya as 'politeness' or 'etiquette', based on the fact that there is a text of that name that refers to the correct actions of kings. Robson is more likely correct that this is an allusion to Indic dance manuals, the element nawa referring to 'nine'. The eight tekes, combined with the king, would therefore make 'nine dances' or nine elements of the performance.

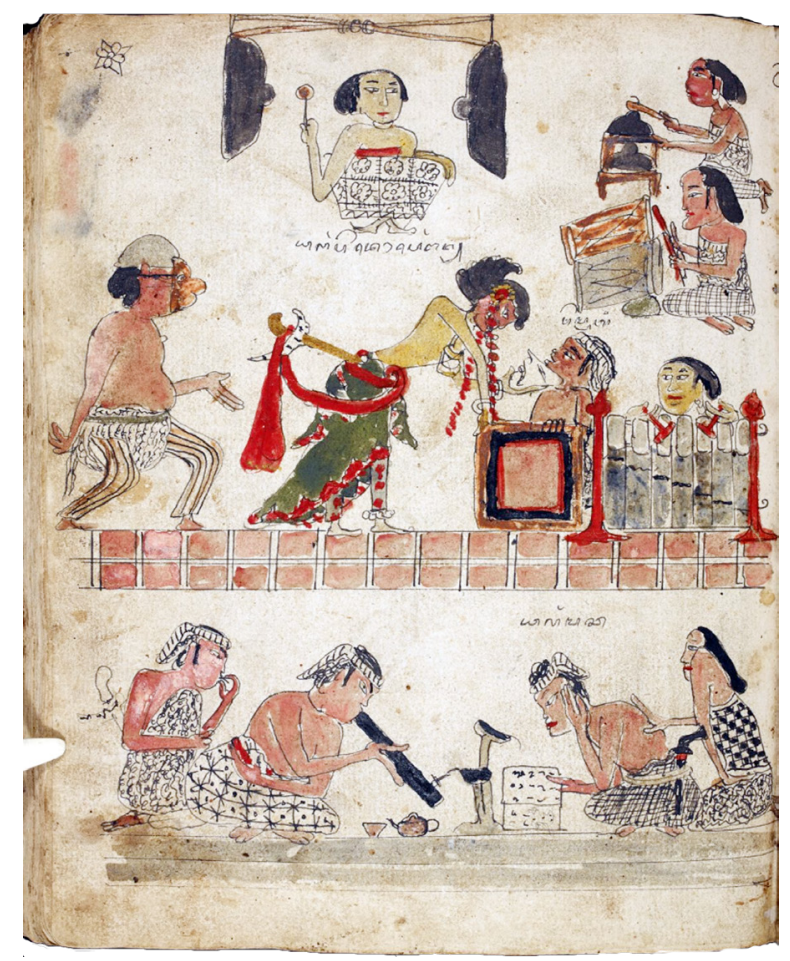

Illustration 1. Topeng performance, Serat Damar Wulan, MSS Jav 89, f.192v, late eightteenth century. (Courtesy of the British Library Board).

This meaning of tekes has significant implications for Panji narratives, as it is central to Kieven's discussion of the iconography of Panji-type figures, who wear caps (2013: 60). In discussing this passage from the Deśawarnana, she draws on older dictionaries that refer to it as a wig or cap of hair or palm bark

problematic. It is the Mpu Tantular Museum copy, made by Dewa Gede Catra, of the Geria Pidada Amlapura manuscript, which is said to be another version of the Deśawarnana copied from an original from Sidemen, which was the place from which the Cakranegara text was copied. The Amlapura and Sidemen texts are not available for outside examination, and it is unclear what changes have been made to the text, since it is said to have been "corrected" in line with the metres (2013: 458-459), giving rise to readings such as mmañjak for mamañjak (91.5a). 9 The word upabharrya only occurs in this text, and Zoetmulder's dictionary (under the word upabhärya) - co-authored with Robson - is tentative about the meaning that is used in Robson's translation, noting that the word does not occur in Sanskrit. It could also mean 'close wives', that is secondary wives close to the king. Pigeaud also offers the possibility that these could be male concubines of the king. 
worn in Javanese topeng performances, which are performances of Panji stories (see IIllustration 1). In Cirebon, tekes "is reserved for a special headdress with a peaked top for Panji in topeng" (Ross 2016: 263), and made of human hair. Such headdresses, as with their equivalents in Balinese gambuh, the gelung, are the subject of special offerings and reverence before performances, since they are vehicles for the realization of the character in the dancer. ${ }^{10}$ Further, in Sundanese, the word gambuh, a kind of head-cloth for topeng performers, is considered synonymous with tekes (Pigeaud 1938: 121; Bandem et al. 1975: 2).

Previously, in discussing the passages from the Deśawarnana, Pigeaud had drawn on his extensive research on Javanese dance, including the Djajadiningrat's research mentioned above, to describe raket as a dance without masks (1938: 125). In this he referred to Malay and later Javanese text, notably the Tantu Panggelaran. Pigeaud linked this text to another performance, and identifies the king as performing three roles, and includes the previous stanza in the same description: Śri (a female role, possibly meaning 'queen'); tekes (based on the head cloth worn in performances) and gitada or 'singer', which in the Tantu Panggelaran is identified with pederet or peret. In his commentary on the Deśawarnana, Pigeaud's explanation of the gitada is that this is the name of a "fixed role", possibly of a religious figure, although this interpretation relies on the word arasuk, 'completely dressed', which seems to be slender evidence for such a view. He does note that the form of upabhärya has a masculine ending, suggesting that the eight accompaniers were men "in travesty", and further that the Sori figure was a "beautiful young man". ${ }^{11} \mathrm{He}$ further identifies the whole performance with the bedaya dance, based on the presence of eight accompanying dancers, which is also a feature of bedaya (Pigeaud 1960 Vol. 4: 318-326). Whether the number is enough to justify the link is open to argument, especially since Ross's documentation of the key set of Cirebon masks provides the information that the five key characters and their four servants replicate the number nine in Javanese cosmology (2016: 295).

While the use of tekes here is not definitive, the Deśawarnana's evidence is enough to indicate the possibility that raket was a kind of performance connected to Panji narratives in the fourteenth century. As will be shown below, this argument is supported by evidence from later Malay texts. From this starting point, we can find not only in the Javanese-Balinese textual tradition, but other related forms, demonstrations that Panji-related performance traditions were a major feature of the movement of the tradition throughout Southeast Asia.

The link between the performance described in the fourteenth-century text and later texts is found in lists of performances such as that in the Nawaruci (86.25), which gives: "aganti kang anggambuh amañcangah alalangkaran mwang awayang cina". In both texts bañcangah is related to storytelling, in later Balinese

\footnotetext{
${ }^{10}$ Discussed at length by Ross, who refers to the passage discussed here, including the other dictionary meanings mentioned above (2016: 263, note 64).

${ }^{11}$ Pigeaud 1938: 508, observes that in Malay texts sori refers to a woman performing a male role, citing the northern Malay Peninsula performance ma'yong, which is also known in southern Thailand.
} 
usage such as the Kidung Pamañcangah specifically historical narratives. Alangkara may refer to wayang or to sung performances, while Chinese wayang could refer to a variety of performances using either humans or puppets.

The words raket and gambuh appear in different contexts from all over the Island of Java. In the Sejarah Banten, which may be contemporary with the Kidung Wangbang Widéya, there is a description of a raket performance. It is held by Pangeran Madura when he adopted Pangeran Anom or Gusti as his son. ${ }^{12}$ The performance is termed a wayang wong, which may refer simply to a drama performed by people. The characters are characters from a Panji story: Panji, Sekartaji, Wirun, Andaga, Kalang, Batara, Gunungsari, Patih Brajanata, Bangbang, Demang, Bramana, Togog, and Panji Anom. There are also records of raket in Cirebon in 1842 held by the Sultan (Djajadiningrat 1913: 66, compare 54; Pigeaud 1938: 125).

As Pigeaud explains, the term gambuh is also found in Madura and East Java, and is recorded at least in the early nineteenth century by Raffles as a martial dance known in West Madura, Pasuruhan, Gresik, and Surabaya (Pigeaud 1938: 198, 457). A horse trance-dance performance mentioned by Pigeaud from Tulungagung, East Java, involved a dukun or shaman-healer who was referred to by the performers as a gambuh (1938: 198). The term is also known to refer to a troop in the guard of the Sultan of Madura, and as a metre with martial associations in Javanese poetry. In the Pasuruhan version of gambuh, it is a group of twenty-four men walking in a procession, armed with kris (Pigeaud 1938: 319). The association with warfare is also clear in Balinese gambuh, which involves martial displays of accompanying characters, and dramatic battle scenes (Vickers 2005).

\section{From JaVAnese to Malay teXt}

Gambuh or similar terms was known in the courts from the island of Borneo that blended Javanese and Malay cultural influences. In an 1838 description of Banjarmasin, gambo refers to a dance, with regular hand movements performed rhythmically to music (Ras 1968: 623). As with the East Javanese and Madurese forms, the dance is associated with the presentation of weapons, notably pikes and bows and arrows. These dances were performed at royal events (see Overbeck 1932a: 15).

The major Malay text of the sultanate, Hikayat Banjar, describes a royal ceremony in which people perform wayang, wayang wong, topeng, rakit, dances (joget), martial displays (baksa) with bows and arrows, spears, shields, upak, tameng, kaner, radap. Cense, Ras's source on this text, equates wayang wong and rakit/raket, but clearly the two are different.

In a Malay text from another sultanate on the same island, the Hikayat Kutai, the term bergambuh is used in a similar way to the Balinese and Javanese usages:

\footnotetext{
${ }^{12} \mathrm{He}$ also has an uncle named Prabangsa, the name of Panji's step-brother in the Malat.
} 
tiada berhenti lagi orang yang sepuluh negeri itu masing-masing langkap dengan permainannya berbagai-bagai ada yang bertandak ada yang berwayang ada yang bertopéng ada yang bergambuh masing-masinglah dengan sukanya dan masing-masing dengan caranya sudah itu maka dibawa oranglah Maharaja Sultan itu ke balai kembang memakai-makai bercancut petola natar (Kutai 225: 35). ${ }^{13}$

Unceasingly the people from ten countries performed, each complete with their own different performances; there were those who sang, those who performed with puppets, those who performed with masks, those each performed gambuh, each with their own pleasures and each with its own style. Thus, the Sultan's people were taken to the floating pavilion dressed up in sarongs with upper cloths of Indian squared fabrics.

Similar lists are found in other Malay texts, particularly Panji texts such as the Hikayat Panji Kuda Semirang, which lists "tandak dan gambuh dan topeng wayang serta rakit" (318: 23), creating the interesting differentiation between forms that might otherwise be considered the same, namely raket as a masked dance, topeng and gambuh. In another part of the same text (185: 19), gambuh seems to refer to a variety of performer, one who like dalang can compose poems:

Diperbuat tembang dan kakawin oleh segala dalang dan gambuh di tanah Jawa. Barang yang memandang dia menjadi edan kasmaran melupakan akan dia dan melupakan makan dan tidur.

All the dalang and gambuh of Java made tembang and kakawin. Whoever watched fell madly in love and forgot food and sleep.

The historical text from Riau, Hikayat Melayu dan Bugis (207: 32), describes a variety of performances: gamelan, topeng, Balinese-style gamelan, gambuh, drums, and martial demonstrations in the Minangkabau style and performances by Chinese bearing flags and fans:

dan yang di hadapan lagi gamelan orang bermain topeng dan yang di hadapan lagi gamelan cara Bali dan yang di hadapan lagi gamelan orang bermain gambuh dan yang di hadapan lagi orang-orang memukul gendang memencak-mencak cara orang Minangkabau dan yang di hadapan permainan orang Cina membawa-bawa mendera-mendera dan kipas.

In the front again was the ensemble of the masked dance performers, and another Balinese-style ensemble, and an ensemble of people performing gambuh, and people playing drums and carrying out martial-arts movements in the Minangkabau style, and performances of Chinese carrying flags and fans.

The Syair Hemop (405) describes a dance "menggambuh cara Bali", "performing gambuh in the Balinese style", in the context of a martial conflict. ${ }^{14}$

${ }^{13}$ This and the following Malay quotations come from Ian Proudfoot's Malay Concordance (Nd).

${ }^{14}$ This is the last of the references taken from Proudfoot's (Nd) Malay Concordance. 
The same phrases listing sets of performances, topeng, raket, gambuh, and others such as the Chinese dramas, are found in numerous other Malay Panji texts, such as the Hikayat Andakan Penurat (Robson 1969: 101-102).

In attempting to sort out these meaning, the earlier lexiconographers of Malay drew on Panji texts, especially the Hikayat Panji Semirang, to try to explicate the meanings of gambuh and raket. Wilkinson (1903) defines gamboh as

The name given to a class of dancing girls who are believed to dance when possessed by the spirits of dancing; a professional dancing girl from Java or Madura. Menjadi gamboh: to become a dancing girl ... Lagu gamboh: the turn played when the puppets in a puppet-show (wayang kulit) are made to dance ...

He defines as "dancers perfectly matched ... these dancers act scenes of medieval Javanese warfare". Van der Tuuk (1897-1912) also used a Malay Panji text, namely the Hikayat Cekel Wanengpati, connected to the Makassarese version of the narrative, which refers to a Majapahit performance of the story of Keladi Merah, where gambuh refers to the dancers as well as the dance. There are numerous references to gambuh in the text, including how the key character Raden Aria Sura Rasmi adopts the name "Gamboh Surana" when in disguise (Zainal 1965: 192-194), and how Arya Prabangsa and his followers disguised as gambuh dancers danced the story of "Jaran Guyang" in a market (Overbeck 1927: 28).

These brief mentions belie the fact that gambuh, raket, and topeng are the subject of more detailed descriptions. Malay texts from present-day Indonesia and Malaysia contain lengthy references to gambuh. Koster's (2018) discussion of the Hikayat Misa Taman Jayeng Kusuma's use of gambuh is illuminating. In that text, as in many other Malay works, Panji and his followers perform gambuh twice. The first time is in the court of Gegelang, inciting desire in the audience through the use of love scenes. Of particular interest to later commentators is the fact that the men take on female roles, in this case in the performance called "The love-sickness of Betara Kangsa Dewa". In the Malay text the instruments are described as selukat, gender, saron, gambang, rebab, kecapi, keromong, and suling. The long flutes (suling) and stringed rebab are the key instruments in Balinese gambuh ensembles, but the other instruments described here are a mixture of those found in Javanese and Balinese ensembles. Kelana Merta Jiwa Sira Panji Maring Daha (Raden Galuh Candra Kirana, the princess in disguise as a man, also known as Prabu Anom and Misa Jejuluk) sings kidung and kakawin. As Koster observes, the performance is a mixture of Indic references to the god Kangsa, and kidung-style narratives (2018: 112-122). The second performance involved Panji and his followers putting on female dress to disguise themselves as gambuh dancers so they can spy on the kingdom of Tambak Kencana. Here too they sing kidung, as an introductory piece by their musical assistants, called panjak. The dancers performed the story of Carang Kembar Kusuma entering the kingdom of Cirebon [in North Java], and in the key episode the performers dressed as mountain hermits (Koster 2018: 122-124).

The gender-shifting here is remarkable enough, since it makes explicit 
elements of same-sex attraction and romance otherwise censored from modern accounts of literature, as Malaysian historian Farish A. Noor makes clear in his discussion of the gambuh performer in Hikayat Panji Semirang (2009: 159166). Remarkable for a different reason is the use of the term panjak to refer to musical accompaniment, a feature of the Deśawarnana's description of raket.

Another Malay Panji text, the lengthy Hikayat Galuh Digantung (Overbeck 1932b), provides further detail. In one section there is a lengthy description of a topeng performance held by Ratu Anom (Panji) at the behest of the PriestKing of Kuripan:

Maka Seri Bengawan Kuripan pun bertitah: Anakku Ratu Anom, apa bicara tuwan, ayahanda ini hendak menyuruh tuwan sekalian bertandak dan menopeng, siapa yang tahu menjadi Śori? Maka sembah Ratu Anom: Jikalau lain deripada anakda yayi ratu tiadalah yang tahu; yang menjadi Peret itu juga patik berlajar, dan yang [...?] Tekar dan yang jadi Cenar itu yayi suri ini salah saorang, masakan tiada tahu. Maka sembah Ratu Anom Singasari: Benar kata kakang itu, ada pun Śori itu sukar orang yang tahu...

Maka Ratu Isteri pun menyembah seraya memandang Ratu Anom lalu berjalan katabir. Maka Permaisuri Daha dan Permaisuri Singasari dan Permaisuri Wirabumi dan Permaisuri Gegelang dan Permaisuri sekalian itu menjadi panjak maka dipalunya gamelan anguran (angrana?) bunyinya, maka pohun Nagasari pun dicocokkan oranglah ditengah tabir itu, maka Śori pun berjalanlah mengirapkan sabuknya, maka terlalu manis lakunya seperti orang bertandak, maka segala yang melihat itupun terlalu heiran iya melihat Ratu Isteri itu seperti lenyap rupanya deripada tempatnya berdiri itu ...

Saketika lagi maka Tekes pun datang diiringkan olah Janti. Adapun yang menjadi Tekes itu Permaisuri Anom, dan yang menjadi Janti itu Paduka Mahadewi. Telah Peret melihat Tekes datang itu, maka kata Peret pada Śori: Lihat tuwan orang yang datang itu, kalaukalau iyalah Kin Cendera Kesuma ...

Thus the Hermit King of Kuripan gave orders: "My son Ratu Anom, what do you say, Your father desires you to dance (tandak) and perform with masks. Who amongst you knows how to play Śori?" Ratu Anom (the young king) replied with a polite gesture, none other than your daughter, my younger sister the queen. I have studied the role of Peret, Tekar [Tekes?] and Cenar [Semar?] can be played by my other younger sisters [wives], how would they not know these? The Young king of Singasari respectfully offered, "What my older brother says is true, Sori is a difficult role"...

The Queen showed her respects while gazing at Ratu Anom; she then went to the curtain. The Queen of Daha, the Queen of Singasari, the Queen of Wirabumi, the Queen of Gegelang and the other queens became the musicians (panjak) and so played the gamelan anguran (?); then the Nagasari tree was placed in the middle of the curtain, so that Sori went down waving her waistcloth, her gestures were exceedingly beautiful, along with those of the dancers, so that all watching were astounded to see the Queen, as if she has vanished on the spot ...

Then the Tekes came, accompanied by Janti. It was the young queen who played Tekes, dan the Princess who played Janti. Peret saw Tekes come, and Peret said to Śri: "Look my Lord at that one who has come, she is like Ken Cendra Kesuma ..." (Overbeck 1932b: 220-223). 
This is a very rich text, and I have omitted much of the commentary on the effects on the audience, who are love-struck and aroused. Overbeck (1932b: 221, note 1) had already discussed this passage with Pigeaud, who advised that it could shed light on the Deśawarnana and the Tantu Panggelaran, and who cited it in his Javaanse Volksvertoningen when analysing the Deśawarnana. Pigeaud was drawing also on Willem Stutterheim's comparison of the two texts which argued that the raket must have been a masked dance, but Pigeaud argues that Stutterheim's interpretation is not supported by the texts (1938: 506). Clearly, Sori and Tekes here are roles that are performed. The mention of tandak is usually taken to refer to dancing, although in Balinese gambuh performances (Illustration 2), the juru tandak is a singer who accompanies the dancers with kidung excerpts. The closeness of this passage to the Deśawarnana confirms that the latter's reference is to some kind of Panji-type performance during Majapahit times. The gender shifting also confirms Pigeaud's view, quoted above, that the Majapahit performance involved same-sex eroticism. The fact that the Majapahit raket was most likely an unmasked dance form, means that it was closer in nature to the Balinese gambuh than to Javanese topeng, which might mean that the Javanese legends linking topeng to the coming of Islam to Java have some credibility.

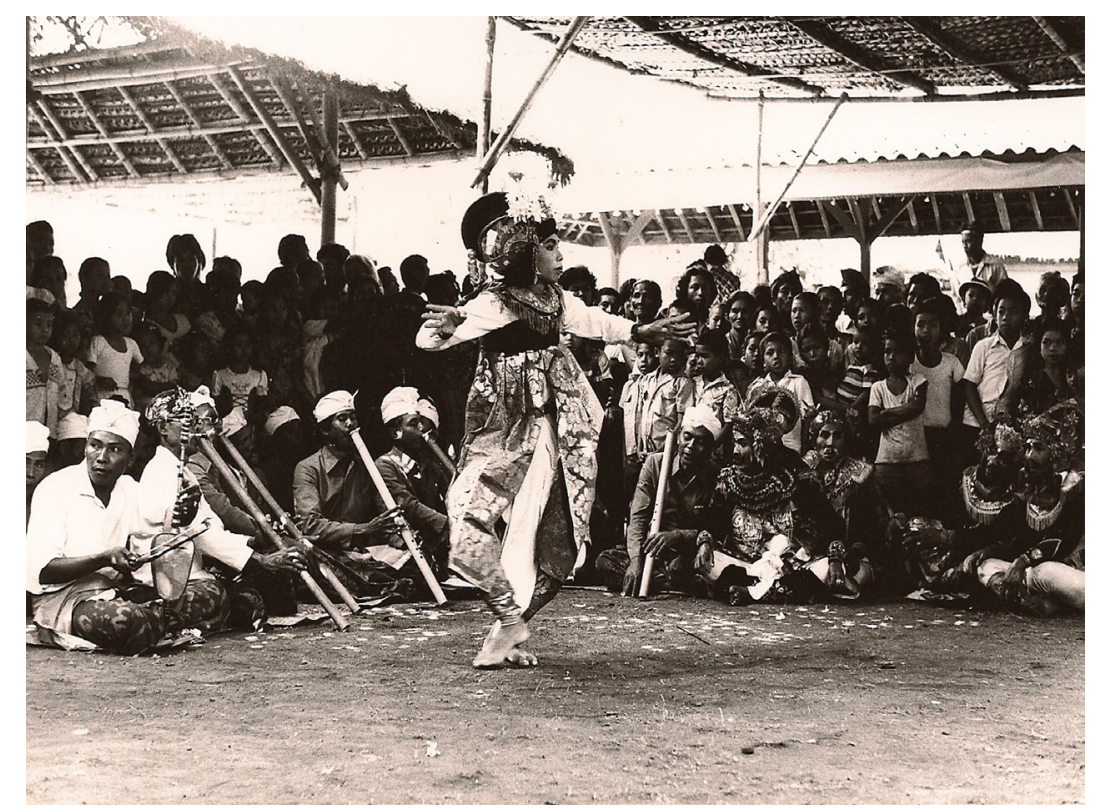

Illustration 2. Balinese gambuh performance, held by the Batuan Gambuh Troupe in October 1981. (Photograph by Adrian Vickers, 1981).

While it is unlikely that the people who put together (dare I say the "composer"?) the Galuh Digantung were familiar with the Deśawarnana, it seems more likely that there was a series of texts, phrases, ideas and motifs 
in circulation in the Southeast Asian coastal world, the Pesisir, in which knowledge of these words crossed languages. Koster's discussion above is concerned with how actions, phrases and names from Hindu kakawin texts operated as "inter-texts" in the Muslim Malay literary world. Ross (2016) also shows how the Panji performances that originated in Majapahit were integrated with Muslim Sufi practices.

\section{CULTURAL INTERACTIONS}

The evidence presented in this brief survey indicates that there was not simply a single thread or path by which Panji stories spread outward from Majapahit Java, eastwards to Bali, westwards throughout Javanese and Sumatra, and northwards through the Malay peninsula to Thailand, Cambodia, and Myanmar. Such a schema is implied in Overbeck's view of the spread of Panji stories (1932a). Rather, the texts show constant processes of mutual interaction and mutual referencing.

"Java" is the major reference point of Panji narratives throughout Southeast Asia (Puaksom 2008). As Robson (1996) drawing on the work of Ras (1968), has already shown, there is clear documentation of a backwards-and-forwards process, for example where people from the Malay sultanate of Banjar in Kalimantan travelled to Java to study. This reference acts centrifugally, as a kind of cultural orientation point. Beyond this, however, as the Malay texts show, is an awareness of a shared cultural zone. That texts from Riau identify Balinese cultural forms speaks of a common set of knowledge of the whole region as a region. I have elsewhere called this a "Panji civilization" (Vickers 2005), but a different way of understanding the mechanics of civilizational connection is to view it as an early example of what Singaporean Sociologist Chua Beng Huat (2015) refers to as "Inter-Asia referencing", the constitution of a cultural landscape through mutual indexing and identification.

\section{REFERENCES}

Anderson, Benedict. 1974. "The last picture show; Wayang beber", in: Proceedings of the Conference on Modern Indonesian Literature, Madison Wisconsin, 28-29 June 1974, pp. 33-81. Madison, WI: Centre for SE Asian Studies, University of Wisconsin.

Bandem, I Made, I Gusti Bagus Arthanegara, Ketut Rota, Ketut Rinda, Nyoman Rembang, and I Gusti Putu Geria. 1975. Panithitalaning Pagambuhan. Denpasar: Proyek Pencetakan/Penerbitan Naskah-Naskah Seni Budaya dan Pembelian Benda-Benda Seni Budaya.

Chua, Beng Huat. 2015. "Inter-Asia referencing and shifting frames of comparison", in: Carol Johnson, Vera Mackie, and Tessa Morris-Suzuki (eds), The Social Sciences in the Asian Century, pp. 67-80. Canberra: ANU Press.

Djajadiningrat, Hoesein. 1913. Critische beschouwing van de Sadjarah Banten; Bijdrage ter kenschetsing van de Javaansche geschiedschrijving. Haarlem: Joh. Enschedé. 
Gunning, J.G.H. 1896. Roorda's Pandji-verhalen in het Javaansch. Leiden: Brill. Hinzler, Hedi. 1981. Bima Swarga in Balinese wayang. The Hague: Nijhoff.

Kant-Achilles, M. 1990. Wayang beber; Das wiederentdeckte Bildrollen-Drama Zentral-Javas. Stuttgart: Franz Steiner Verlag.

Kieven, Lydia. 2013. Following the cap-figure in Majapahit temple reliefs; A new look at the religious function of East Javanese temples, fourteenth and fifteenth centuries. Leiden: Brill.

Koster, Gijs. 2018. "Ramayana and Mahabharata in Hikayat Misa Taman Jayeng Kusuma", in: Ding Choo Ming and Willem van der Molen (eds), Traces of the Ramayana and Mahabharata in Javanese and Malay Literature, pp. 99-136. Singapore: ISEAS.

Moura, J. 1883. Le royaume du Cambodge. Paris: Librare de la Société Asiatique de l'École des Langues Orientales Vivantes. Two vols.

Noor, Farish A. 2009. What your teacher didn't tell you; The annexe lectures. Vol. 1. Kuala Lumpur: Matahari Books.

Overbeck, H.O. 1927. “De ouderdom van de wayang wong”, Djårwå 7: 245-252.

Overbeck, H.O. 1932a. "Eenige opmerkingen naar aanleiding van Over den oorsprong van het Javaansche tooneel, door Dr W.H. Rassers", Djåwå 12: 11-20.

Overbeck, H.O. 1932b. "Java in de Maleische literatuur (Hikajat Galoeh diGantoeng)", Djåwå 12: 209-228.

Pigeaud, Th. 1938. Javaanse volksvertoningen; Bijdrage tot de beschrijving van land en volk. Batavia: Volkslectuur.

Pigeaud, Th.G.T. 1960-1962. Java in the fourteenth century; A study in cultural history. The Nagara-Kěrtagama by Rakawi Prapañca of Majapahit, 1365 AD. The Hague: Nijhoff. Five vols.

Poerbatjaraka, R.M.Ng. 1940. Pandji-verhalen onderling vergeleken. Bandung: Nix. [Translated 1968 Tjeritera Panji dalam perbandingan. Djakarta: Gunung Agung.]

Proudfoot, Ian. Nd. Malay Concordance Project<mcp.au.edu.au>.

Puaksom, D. 2007. The pursuit of Java: Thai Panji stories, Melayu lingua franca and the question of translation. PhD thesis, National University of Singapore.

Ras, J.J. 1968. Hikajat Bandjar; A study in Malay historiography. The Hague: Nijhoff.

Riana, I Ketut. 2009. Kakawin Dēśa Warṇnana uthawi Nāgara Kṛtāgama; Masa keemasan Majapahit. Jakarta: Kompas.

Rinda, I Ketut and R. Moerdowo. 1973. “Beberapa tari Bali yang bersumber pada tari Gambuh". [Working paper for the Gambuh Workshop, 25 August-1 September 1973. Denpasar.]

Robson, S.O. 1969. Hikajat Andaken Penurat. The Hague: Nijhoff.

Robson, S.O. 1971. Wangbang Widéya; A Javanese Panji romance. The Hague: Nijhoff.

Robson, S.O. 1995. Deśawarnana (Nāgarakrtāgama) by Mpu Prapañca. Leiden: KITLV Press.

Robson, S.O. 1996. "Panji and Inao; Questions of cultural and textual history", Journal of the Siam Society 84/2: 39-53. 
Ross, Laurie Margot. 2016. The encoded Cirebon mask; Materiality, flow, and meaning along Java's Islamic Northwest Coast. Leiden: Brill.

Saleh, Rattiya. 1988. Panji Thai dalam perbandingan dengan cerita-cerita Panji Melayu. Kuala Lumpur: Dewan Bahasa dan Pustaka.

Sayid, R.M. 1980. Bauwarna kawruh wayang; Sejarah wayang beber. With synopsis and translation by Joseph Errington. Solo: Reksa Pustaka.

Tuuk, H.N. van der. 1897-1912. Kawi-Balineesch-Nederlandsch woordenboek. Batavia: Landsdrukkerij. Four vols.: Vol. I. 1897, Vol. II. 1899, Vol. III. 1901, Vol. IV. 1912.

Vickers, A. 2005. Journeys of desire; A study of the Balinese text Malat. Leiden: KITLV Press.

Wilkinson, R.J. 1903. A Malay-English dictionary. Singapore: Kelly and Walsh. Zainal, Bahruddin (ed.). 1965. Hikayat Chekel Waneng Pati. Kuala Lumpur: Dewan Bahasa dan Pustaka.

Zoetmulder, Piet J. 1982. Old Javanese-English dictionary. With the collaboration of S.O. Robson. 's Gravenhage: Nijhoff. Two vols. 